\title{
NON PERFORMING LOAN (NPL) DAN RETURN ON ASSET (ROA) DI KOPERASI NUSANTARA MUARA BUNGO
}

\section{${ }^{1}$ Sasmita Rusnaini, ${ }^{2}$ Hamirul, ${ }^{3}$ Ariyanto.M}

\section{âuest}

${ }^{1,2,3}$ Sekolah Tinggi IImu Administrasi Setih Setio Korespondensi: hrul@ymail.com

Artikel ini tersedia dalam: http://journal.stiemb.ac.id/inde x.php/mea

DOI:10.31955/mea.vol3.iss1.pp1-18

Vol. 3 No. 1 Januari-April 2019

e-ISSN: 2621-5306

p-ISSN: 2541-5255

\section{How to Cite:}

Rusnaini, S., Hamirul, H., \& M, A. (2019). NON PERFORMING LOAN (NPL) DAN RETURN ON ASSET (ROA) DI KOPERASI NUSANTARA MUARA BUNGO. Jurnal IImiah MEA (Manajemen, Ekonomi, \& Akuntansi), 3(1), 1-18

Copyright (c) 2019 Jurnal IImiah MEA (Manajemen, Ekonomi, \& Akuntansi)

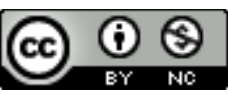

This work is licensed under a Creative Commons Attribution-NonCommercial 4.0 International License

\begin{abstract}
ABSTRAK: Artikel ini bertujuan untuk mengetahui Pengaruh Non Performing Loan (NPL) terhadap Return On Asset di koperasi Nusantara Muara Bungo, dengan menggunakan Metode deskriptif dengan pendekatan Kuantitatif. Hasil penelitian Dari hasil penelitian menunjukkan variabel NPL berpengaruh negatif dan signifikan terhadap ROA. Artinya, setiap perubahan yang terjadi pada variabel independen yaitu NPL akan berpengaruh pada ROA di Koperasi Nusantara KCP Muara Bungo. Secara parsial variabel NPL berpengaruh negatif terhadap ROA pada Koperasi Nusantara. Tanda negatif menunjukkan perubahan yang berlawanan atau berbanding terbalik, yaitu jika variabel (X) NPL meningkat maka variabel (Y) ROA akan menurun. Sebaliknya apabila variabel (X) NPL menurun maka variabel (Y) ROA akan meningkat .
\end{abstract}

Kata Kunci : NPL. ROA, Koperasi Nusantara, Kabupaten Bungo

\begin{abstract}
This article aims to determine the Effect of Non Performing Loans (NPL) on Return On Asset in the Nusantara Muara Bungo cooperative, using descriptive methods with a quantitative approach. The results of the study From the results of the study indicate the variable NPL has a negative and significant effect on ROA. That is, any changes that occur in the independent variable, NPL, will affect ROA at Muara Bungo KCP Nusantara Cooperative. Partially the NPL variable has a negative effect on ROA in Nusantara Cooperatives. A negative sign indicates a change that is opposite or inversely proportional, that is if the variable $(X)$ $N P L$ increases then the variable $(Y)$ ROA will decrease. Conversely, if the variable $(X) N P L$ decreases, the variable (Y) ROA will increase.
\end{abstract}

Keywords: NPL. ROA, Koperasi Nusantara, Bungo Regenc 


\section{PENDAHULUAN}

Hampir di seluruh dunia mengenal kata Koperasi. Koperasi merupakan satu-satunya bentuk usaha yang termuat dalam Pasal 33 ayat (1) Undang-Undang Dasar Negara Republik Indonesia Tahun 1945 ditegaskan bahwa "perekonomian disusun sebagai usaha bersama berdasar atas asas kekeluargaan". Ketentuan tersebut sesuai dengan prinsip Koperasi, karena itu Koperasi mendapat misi untuk berperan nyata dalam menyusun perekonomian yang berdasar atas asas kekeluargaan dan demokrasi ekonomi yang mengutamakan kemakmuran masyarakat bukan kemakmuran orang seorang.

Definisi koperasi di Indonesia, dijelaskan dalam Undang-Undang Nomor 17 Tahun 2012 Pasal 1 bahwa koperasi adalah badan hukum yang didirikan oleh orang perseorangan atau badan hukum Koperasi, dengan pemisahan kekayaan para anggotanya sebagai modal untuk menjalankan usaha, yang memenuhi aspirasi dan kebutuhan bersama di bidang ekonomi, sosial, dan budaya sesuai dengan nilai dan prinsip Koperasi. Sedangkan Koperasi Simpan Pinjam merupakan koperasi yang menjalankan usaha simpan pinjam sebagai satu-satunya usaha dalam melayani anggota (Pasal 84 UU No 17/2012).

Semakin berkembangnya kegiatan Koperasi di Indonesia maka tuntutan agar pengelolaan Koperasi dilaksanakan secara lebih profesional akan semakin besar. Pengelolaan tersebut memerlukan adanya sistem pertanggungjawaban yang baik dan informasi yang relevan serta dapat diandalkan dalam pengambilan keputusan, perencanaan maupun pengendalian. Keberhasilan Koperasi ditentukan oleh kemampuannya dalam mentransformasikan diri sesuai dengan tuntutan perubahan dan memperkuat budaya yang mendukungnya.

Berawal dari perhatian terhadap keterbatasan perkembangan dunia perkoperasian di Indonesia yang seharusnya dapat menjadi soko guru perekonomian nasional membuat sekelompok generasi muda dengan latar belakang keuangan dan teknologi informatika terpacu untuk menghadirkan Koperasi yang memanfaatkan teknologi untuk pengembangan bisnisnya.

Koperasi Nusantara bekerjasama dengan perbankan melalui linkage program dengan fasilitas channeling, melalui kerjasama tersebut Koperasi Nusantara membantu memberikan pinjaman kepada calon debitur yang membutuhkan. Kegiatan utama dari Koperasi Nusantara ini adalah jasa konsultan keuangan, agen pemasaran dari berbagai perusahaan barang/jasa. Sistem koperasi di Indonesia juga memiliki fungsi-fungsi koperasi, dan salah satunya telah dianut oleh Koperasi Nusantara yaitu fungsi sosial dan fungsi etika apa yang harus diterapkan dalam komunikasi. Berbasis teknologi informatika, memungkinkan Koperasi Nusantara dapat melakukan pengelolaan bisnisnya dengan realtime online system di seluruh cabang layaknya standar penbankan di Indonesia.

Kemitraan strategis untuk dapat menjalankan bisnis yang ada dengan baik tidak hanya dibangun dengan pihak PT. Pos Indonesia tapi juga dengan pihak-pihak pendukung lainnya seperti Bank BCA, Bank BCA Syariah, Bank BNI, Bank BNI Syariah, Bank Bukopin, Bank Panin, Bank Panin Syariah, Bank BKE, Asuransi Jiwasraya.

Pinjaman yang diberikan oleh Koperasi Nusantara kepada debitur pensiunan TASPEN dan ASABRI ditetapkan untuk jangka waktu maksimal 15 tahun dengan rate perbulan dimulai dari $0,85 \%$ sampai dengan $1,2 \%$ dan besar pinjaman maksimal Rp 200.000.000,-. Untuk maksimal pemotongan angsuran kredit yaitu $95 \%$ dari gaji bersih diluar tanggungan anak dan usia jatuh tempo debitur sampai dengan usia 72 Tahun. Dengan agunan yang digunakan dalam proses kredit tersebut yaitu merupakan SK pensiun Asli debitur tersebut. 
Koperasi Nusantara menyediakan dana yang relatif mudah untuk di dapat oleh para pensiunan yang mengambil gaji di PT. Pos Indonesia dan untuk mendapatkan dana yang telah disetujui oleh kedua belah pihak antara debitur dengan Koperasi Nusantara debitur hanya melengkapi persyaratan terlampir, setelah persyaratan diseleksi oleh pihak kreditur dan dinyatakan bisa untuk pengajuan pinjaman baik dilihat dari SK Asli atau agunan, maupun dilihat dari usia dan kesehatan fisik debitur maka pengajuan akan diproses untuk penginputan oleh petugas Koperasi Nusantara dan melewati proses asuransi yang melihat dari hasil foto debitur yang masih dinyatakan sehat untuk pengajuan pinjaman setelah proses approval asuransi lolos langsung ke proses verifikasi yang berguna untuk memproses dan pengecekan kelayakan berkas debitur tersebut dan kemudian proses verifikasi berkas berhasil maka ke tahap terakhir approval kredit yang berfungsi untuk pengecekan keseluruhan dan menyatakan layak debitur tersebut dapat diberi pinjamana dan dapat disetujui. Dan barulah pihak keuangan mentransfer dana ke cabang dan kcp untuk dilanjuti ke tangan debitur yang berhak menerimanya. Syarat lengkap Koperasi Nusantara bisa mencairkan dana tersebut dalam waktu satu hari.

Kemampuan manajemen dalam menyusun rencana kerja, rencana pendapatan, dan belanja yang disusun setiap tahun secara efektif dan efesien serta adanya pengendalian operasional juga factor yang turut diperhatikan, dan dengan mengukur kinerja keuangan Koperasi. Kinerja keuangan koperasi merupakan cerminan seberapa jauh mana hasil yang didapatkan dalam menjalankan kegiatan usahanya. Apakah kinerja Koperasi menunjukkan kenaikan atau mengalami penurunan.

Kemampuan Koperasi dalam menghasilkan profitabilitas akan bergantung kepada kemampuan manajemen yang bersangkutan dalam mengelola asset dan liabilities yang ada. Salah satu ukuran untuk melihat kinerja keuangan adalah melalui Return On Asset (ROA). Berdasarkan Surat Edaran BI SE No.13/24/DPNP tanggal 25 Oktober 2011, rasio ROA dapat diukur dengan perbandingan antara laba sebelum pajak terhadap total aset (total aktiva). Semakin besar ROA akan menunjukkan kinerja keuangan yang semakin baik, karena tingkat pengembalian (return) semakin besar.

Adapun hambatan-hambatan yang dilakukan oleh pihak bank kepada masyarakat, dan semakin berkembangnya perkreditan di dunia bisnis saat ini maka dengan ini multifinance dan koperasi melihat peluang bisnis yang baik untuk menjalankan kerjasama dengan bank dalam penyampaian kredit kepada masyarakat, yang disebut sebagai channeling. Channeling yaitu cara penyaluran pinjaman yang diberikan oleh bank kepada debitur melalui koperasi yang bertindak sebagai agent dan tidak mempunyai kewenangan memutus kredit kecuali mendapat surat kuasa dari bank. Bank memberikan pembiayaan secara langsung kepada debitur sebagai and user melalui perusahaan mitra yang bertindak sebagai agen, saat debitur tidak melakukan pembayaran, maka koperasi akan tetap membayar kepada bank.

Dan untuk prosedur pemotongan angsurannya ke Koperasi Nusantara dilaksanakan oleh pihak juru bayar pensiun PT. Pos Indonesia saat pensiunan mengambil gajinya, jadi pensiuanan atau debitur Koperasi Nusantara hanya menerima sisa gaji yang sudah dipotong oleh pihak PT. Pos Indonesia. Jika pensiunan tidak mengambil gaji pihak PT. Pos Indonesia tidak berhak/memotongkan kan langsung angsuran kredit debitur tersebut untuk Koperasi Nusantara karena banyak alasan pihak PT. Pos Indonesia seperti pensiunan tersebut meninggal dunia dan pensiunan janda atau duda yang sudah menikah lagi, 
hal seperti ini menjadikan NPL bagi Koperasi Nusantara.

Koperasi juga tidak asal meningkatkan jumlah dan tingkat suku bunga penyaluran kreditnya. Untuk menghindarkan risiko kredit macet NPL yang tinggi dari penyaluran kredit yang tidak efisien. Dalam hal ini perlu untuk mempertimbangkan alokasi dana yang efisien. Seperti penyaluran kredit yang bisa memberikan return yang tinggi dimana tingkat NPL tidak terlalu tinggi. Karena pengalokasian dana yang tepat sangat mempengaruhi jumlah modal.

Pada dasarnya semua bisnis tidak terlepas dari risiko kegagalan. Pemberian kredit yang dilakukan mengandung risiko yaitu berupa tidak lancarnya pembayaran kredit atau dengan kata lain kredit bermasalah NPL sehingga akan mempengaruhi kinerja perusahaan.

Semakin tinggi rasio NPL maka akan semakin buruk kualitas kredit yang menyebabkan kerugian, sebaliknya jika semakin rendah NPL maka laba atau profitabilitas koperasi ROA tersebut akan semakin meningkat.

NPL yang merupakan proksi dari risiko kredit juga berhubungan dengan profitabilitas. NPL atau kredit bermasalah adalah salah satu alat penilaian kualitas aset dengan kualitas kurang lancar, diragukan, dan macet sebagaimana diatur dalam ketentuan Bank Indonesia melalui SE BI No. 15/28/DPNP 31 Juli 2013 dengan batas maksimal adalah 5\%. Dalam kondisi normal, maka NPL yang tinggi akan menurunkan profitabilitas.

Adapun fenomena NPL yang terjadi pada Koperasi Nusantara KCP Muara Bungo yaitu macetnya pembayaran kredit pensiun debitur An. Rachmawati yang mengalami tunggakan hingga 19 Bulan dikarenakan debitur ini mempunyai kriteria yang tidak baik, yang berani menggandakan SK Pensiun yang mana SK pensiun tersebut adalah jaminan kredit pada Koperasi
Nusantara. Dengan mempunyai SK pensiun yang ganda, debitur tersebut mampu melakukan akad kredit baru dengan kreditur lain serta memindahkan kantor bayar pensiunnya secara sepihak. Hal yang dilakukan debitur tersebut membuat gaji pensiunnya pindah dan tidak terbit lagi di PT. Pos Indonesia yang menyebabkan tagihan kredit pada Koperasi Nusantara tidak bisa di potongkan melalui PT. Pos Indonesia sehingga macet dalam pembayarannya. Akibat dari macetnya kredit tersebut menjadikan NPL pada Koperasi Nusantara KCP Muara Bungo, dan Koperasi Nusantara sebagai channeling dari bank tentunya akan tetap bertanggung jawab kepada Bank tersebut untuk membayar tagihan debitur, dan hal inilah yang menyebabkan asset pada Koperasi Nusantara menjadi menurun. Hal tersebut merupakan salah satu penyebab terjadinya NPL yang mengakibatkan penurunan pada ROA.

Berikut besaran persentase NPL dan ROA yang terjadi pada Koperasi Nusantara KCP Muara Bungo yang bisa dilihat pada table.1 dan Tabel.2

\section{TINJAUAN LITERATUR}

\section{Non Performing Loan (NPL)}

Non Performing Loan (NPL) merupakan rasio keuangan yang menunjukkan risiko kredit yang dihadapi akibat pemberian kredit dan investasi dana pada portofolio yang berbeda. Non Performing Loan (NPL) atau kredit bermasalah dapat dikelompokkan menjadi tiga, yaitu :

1) Kredit kurang lancar

Kredit kurang lancar merupakan kredit yang telah mengalami tunggakan dengan kriteria sebagai berikut :

a) Pengembalian pokok pinjaman dan bunganya telah mengalami penundaan pembayarannya 
melampaui 90 hari sampai dengan kurang dari 180 hari.

b) Pada kondisi ini hubungan debitur dan kreditur memburuk.

c) Informasi keuangan debitur tidak dapat diyakini oleh kreditur.

2) Kredit diragukan

Kredit diragukan merupakan kredit yang mengalami penundaan pembayaran pokok dan bunga dengan kriteria berikut :

a) Penundaan pembayaran pokok dan bunga antara 180 hingga 270 hari.

b) Pada kondisi ini hubungan debitur dengan kreditur semakin memburuk.

c) Informasi keuangan sudah tidak dapat dipercaya.
3) Kredit macet

Kredit macet merupakan kredit yang menunggak melampaui 270 hari atau lebih.

Setiap penanaman dana perlu dinilai kualitasnya dengan menentukan tingkat kolektibilitas yaitu apakah lancar, diragukan atau macet. Berdasarkan SE BI No. 17/19/DPUM tanggal 8 Juli 2015 ditetapkan bahwa rasio NPL tidak boleh lebih dari $5 \%$.

Setiap kreditur harus mengetahui tingkat kolektibilitas dari kredit yang diberikan. Hal ini diperlukan untuk mengetahui besarnya cadangan minimum penghapusan aktiva produktif yang harus disediakan oleh kreditur untuk menutup kemungkinan kerugian yang terjadi. Berdasarkan SE BI Nomor 13/30/DPNP tanggal 16 Desember 2011 perhitungan NPL dapat diperoleh dengan cara sebagai berikut:

$$
N P L=\frac{\text { Kredit Bermasalah }}{\text { Total Kredit }}
$$

Dalam kondisi normal, kreditur mengandalkan komponen kredit untuk memperoleh earning assetnya. Artinya bahwa kreditur memperoleh pendapatan dengan mengandalkan pada bunga kredit yang dipinjamkan selain dari obligasi rekapitulasi. NPL yang tinggi akan berakibat pada menurunnya pendapatan bunga yang akan diterima oleh kreditur, bahkan jika terjadi kredit macet maka akan berdampak pada timbulnya kerugian.

\section{Return On Asset (ROA)}

ROA digunakan untuk mengukur efektivitas perusahaan di dalam menghasilkan keuntungan dengan memanfaatkan aktiva/aset yang dimilikinya. Dengan kata lain, rasio ini digunakan untuk mengukur kemampuan manajemen dalam memperoleh keuntungan (laba) secara keseluruhan. Semakin besar ROA semakin besar pula tingkat keuntungan yang dicapai kreditur tersebut dan semakin baik pula posisi perusahaan trsebut dari segi penggunaan aset.

ROA atau sering diterjemahkan ke dalam Bahasa Indonesia sebagai rentabilitas ekonomi mengukur kemampuan perusahaan dalam menghasilkan laba pada masa lalu. Analisis mengenai ROA kemudian bisa diproyeksikan ke masa depan untuk melihat kemampuan perusahaan dalam menghasilkan laba pada masa mendatang. ROA mengukur kemampuan perusahaan menghasilkan laba dengan menggunakan total asset (kekayaan) yang dimiliki perusahaan setelah disesuaikan dengan biaya-biaya untuk mendanai aset tersebut.

ROA adalah alat untuk menganalisis atau mengukur tingkat efisiensi usaha dan profitabilitas yang dicapai. ROA digunakan untuk mengukur kemampuan manajemen dalam memperoleh (laba) secara keseluruhan. Selain merupakan ukuran 
profitabilitas, ROA sekaligus merupakan indikator efisiensi manajerial yang mengindikasikan kemampuan manajemen dalam mengelola aset-asetnya untuk memperoleh keuntungan.

Sesuai dengan Surat Edaran yang dikeluarkan oleh Bank Indonesia yakni SE No.13/24/DPNP tanggal 25 Oktober 2011, ketentuan untuk ROA minimal yang ideal bagi bank adalah 1,50\%. Artinya bahwa jika bank memperoleh keuntungan di bawah nilai yang ditetapkan oleh Bank Indonesia maka bank tersebut dinyatakan masih belum optimal dalam mengelola asetnya.

Berdasarkan SE BI No. 13/30/DPNP tanggal 16 Desember 2011, rumus yang digunakan dalam perhitungan ROA adalah sebagai berikut :

$$
R O A=\frac{\text { Laba Sebelum Pajak }}{\text { Rata }- \text { Rata Total Aset }}
$$

Sumber dana terbesar bank berasal dari simpanan masyarakat. Maka semakin besar ROA, semakin besar pula tingkat keuntungan yang dicapai kreditur tersebut dan semakin baik pula posisi koperasi tersebut dari segi penggunaan aset.

\section{Hubungan Variabel Non Performing Loan} (NPL) Terhadap Return On Asset (ROA)

Semakin tinggi rasio NPL maka akan semakin rendah kualitas kredit yang menyebabkan jumlah kredit bermasalah semakin besar maka perusahaan dalam kondisi berisiko. Terjadinya NPL yang berakibat pada timbulnya ROA yang semakin menurun pada perusahaan. Karena ROA mencerminkan kinerja laba yang sudah memperhitungkan aset yang dimiliki.

\section{METODE PENELITIAN}

Penelitian yang akan dilakukan menggunakan penelitian data kuantitatif yang berbentuk bilangan atau angka-angka dan pendekatan kuantitatif ini untuk menguji hipotesis. Penelitian ini akan menjelaskan mengenai pengaruh NPL terhadap ROA, penelitian ini dilakukan pada Koperasi Nuasantara KCP Muara Bungo.

\section{Jenis dan Sumber Data}

\section{Jenis Data}

Jenis data yang digunakan dalam penelitian ini adalah data sekunder berupa time series dengan kurun waktu perbulan periode tahun 2012-2015. Data sekunder adalah data yang diperoleh atau dikumpulkan peneliti dari sumber yang telah ada.

2. Sumber Data

Data yang digunakan dalam penelitian ini adalah berupa data laporan keuangan. Data laporan keuangan yang diperoleh dari Koperasi Nusantara yang dibuat perbulan selama 48 bulan.

\section{Tehknik Pengumpulan Data}

\section{Dokumentasi}

Metode dokumentasi diperoleh dengan cara mengutip secara langsung dari laporan keuangan bulanan Koperasi Nusantara sebanyak 48 Bulan periode

Tahun 2012-2015.

\section{Studi Pustaka}

Studi pustaka yang dilakukan dengan cara membaca tulisan-tulisan yang berhubungan dengan topik yang akan dibahas dan teori yang relevan dengan permasalahan yang akan diteliti. Serta mempelajari bahan pustaka lainnya yang mempunyai hubungan dengan risiko kredit, seperti buku, jurnal dan penelitian terdahulu.

\section{Definisi Operasional Variabel}

Pada dasarnya penentuan variabel penelitian merupakan operasionalisasi kontrak supaya dapat diukur. Dalam penelitian ini, operasional variabel penelitian 
dan pengukuran variabel dapat dilihat dari tabel 4

\section{Tekhnik Analisis Data}

Teknik analisis data yang digunakan dalam penelitian ini adalah analisis regresi linear. Analisa data menggunakan software SPSS (Statistical Package for The Social Science) versi 20.

\section{Model Analisis}

\section{Regresi Linier Sederhana}

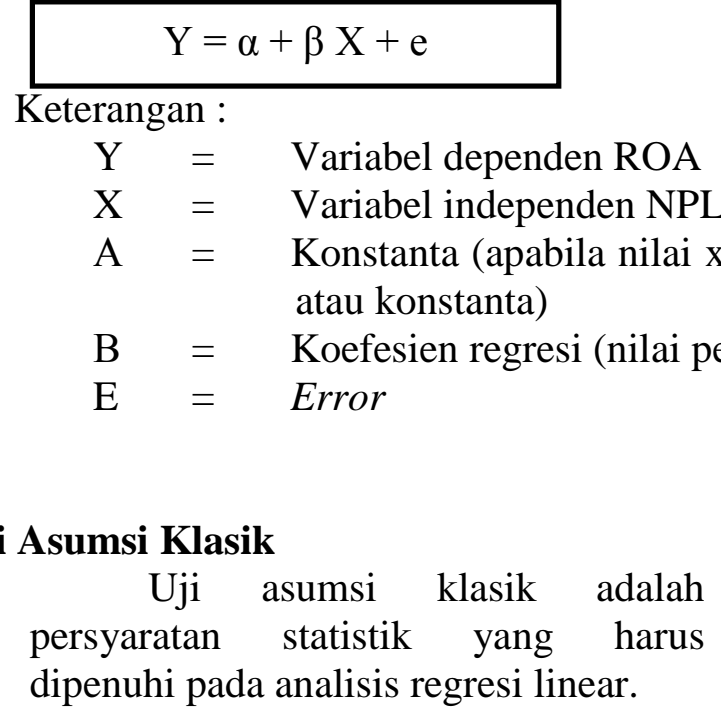

\section{Uji Normalitas}

Uji normalitas bertujuan untuk menguji apakah dalam model regresi, variabel pengganggu atau residual memiliki distribusi normal. Seperti diketahui bahwa uji $\mathrm{t}$ mengasumsikan bahwa nilai residual mengikuti distribusi normal. Kalau asumsi ini dilanggar maka uji statistik menjadi tidak valid untuk jumlah sampel kecil.

\section{Uji Autokorelasi}

Uji autokorelasi bertujuan menguji apakah dalam model regresi linear ada korelasi antara kesalahan pengganggu pada periode $\mathrm{t}$ dengan kesalahan pengganggu pada periode t-I (sebelumnya). Jika terjadi korelasi, maka dinamakan ada
Regresi linear sederhana dapat didefinisikan sebagai pengaruh antara 2 variabel saja, dimana terdiri dari 1 variabel independent/bebas dan 1 variabel dependent (terikat) dan juga digunakan untuk membangun persamaan dan menggunakan persamaan tersebut untuk membuat perkiraan (prediction). Rumus persamaan regresi sederhana dapat dijabarkan sebagai berikut :

problem autokorelasi. Autokorelasi muncul karena observasi yang berurutan sepanjang waktu berkaitan satu sama lainnya. Masalah ini timbul karena residual (kesalahan pengganggu) tidak bebas dari satu observasi ke observasi lainnya. Hal ini sering ditemukan pada data runtut waktu (time series) karena "gangguan" pada seseorang individu /kelompok cenderung mempengaruhi "gangguan" pada individu/kelompok yang sama pada periode berikutnya.

Uji autokorelasi digunakan untuk mengetahui apakah ada korelasi antara kesalahan pengganggu pada periode $\mathrm{t}$ dengan kesalahan pada periode t sebelumnya pada model regresi linear yang digunakan. Jika terjadi korelasi, maka dinamakan ada problem autokorelasi. Untuk mendeteksi terjadinya autokorelasi atau tidak dalam suatu model regresi dilakukan dengan melihat nilai statistik Durbin Watson (DW). Pendeteksian ada 
tidaknya gejala autokorelasi adalah sebagai berikut : jika angka D-W dibawah -2 , berarti ada autokorelasi negatif sedangkan jika angka D-W diantara -2 sampai 2, maka tidak ada autokorelasi dan jika angka D-W diatas +2 , berarti ada autokorelasi positif.

\section{Pengujian Hipotesis (Uji Statistik t)}

Uji statistik $t$ pada dasarnya menunjukkan seberapa jauh pengaruh satu variabel independen secara individual dalam

\section{Koefisien Determinasi}

Koefisien determinasi $\left(\mathrm{R}^{2}\right)$ pada intinya mengukur seberapa jauh kemampuan model dalam menerangkan variasi variabel dependen. Bila koefisien determinasi adalah nol dan satu. Nilai $\mathrm{R}^{2}$ yang kecil berarti kemampuan variabel-variabel independen dalam menjelaskan variasi variabel dependen amat terbatas. Nilai yang mendekati satu berarti variabel-variabel independen memberikan hampir semua informasi yang dibutuhkan untuk memprediksi variasi variabel dependen.

\section{HASIL DAN DISKUSI}

Analisis Deskriptif

\section{Analisis Deskriptif Non Performing Loan (NPL)}

Non Performing Loan (NPL) atau penyebab kredit menjadi bermasalah dapat dilihat dari dua sisi (dari sisi debitur dan dari sisi kreditur), yaitu berikut ini.

1. Dari sisi debitur

a. Sikap kooperatif debitur menurun dan adanya itikad yang kurang baik dari debitur.

b. Kredit yang diterima tidak digunakan untuk tujuan yang seharusnya sebagaimana yang diperjanjikan dengan kreditur.

c. Strategi usaha tidak tepat.

d. Konflik di dalam manajemen, organisasi dan kepegawaian menerangkan variasi variabel dependen. Hipotesis nol (Ho) yang yang hendak diuji adalah suatu parameter (bi) sama dengan nol, atau :

$$
\text { Ho ; bi }=0
$$

Artinya, suatu variabel independen bukan merupakan penjelas yang signifikan terhadap variabel dependen.

$$
\mathrm{Ha} ; \mathrm{bi} \neq 0
$$

Artinya, variabel independen merupakan penjelas yang signifikan terhadap variabel dependen.

(untuk debitur yang merupakan badan usaha).

2. Dari sisi kreditur

a. Analisa kredit yang kurang memadai dari kreditur sehingga terjadinya ketidaktepatan dalam penilaian risiko dan mitigasinya, serta timbulnya over financing (kredit yang diberikan lebih besar dari kebutuhan debitur).

b. Pemantauan terhadap fasilitas kredit yang telah diberikan kepada debitur kurang memadai (lemah).

c. Adanya fraud yang dilakukan oleh karyawan terkait dengan penyaluran kredit kepada debitur.

d. Penguasaan agunan yang lemah, baik dari objek/fisik agunan maupun pengikatannya.

Non Performing Loan (NPL) juga merupakan faktor yang sangat penting bagi penilaian kinerja perkreditan, bahkan hampir semua rasio nilainya dipengaruhi oleh NPL. Berdasarkan SE BI No. 17/19/DPUM tanggal 8 Juli 2015 ditetapkan bahwa rasio NPL tidak boleh lebih dari 5\%. Semakin rendah NPL semakin baik kinerja perusahaan karena jumlah kredit yang bermasalah/macet semakin kecil, begitu pula sebaliknya semakin tinggi NPL maka akan semakin besar kredit yang bermasalah/macet 
pada perusahaan tersebut. NPL yang digunakan adalah NPL pada Koperasi Nusantara KCP Muara Bungo.

Data NPL yang digunakan adalah perkembangan NPL pada Koperasi Berdasarkan Tabel 5 di atas menunjukkan perkembangan tingkat NPL pada Koperasi Nusantara periode tahun 2012 - 2015. Pada masa penelitian ini NPL terendah terjadi pada bulan Juli 2013 yaitu sebesar 0,0536, Grafik diatas menunjukkan kecenderungan NPL yang mengalami fluktuasi pada Koperasi Nusantara periode tahun 2012 2015, dapat dilihat pada grafik diatas NPL meningkat pada bulan Nopember 2012 disebabkan banyaknya debitur yang tidak mengambil gaji dan menyebabkan tingginya tingkat NPL. Dan dibulan berikutnya menurun dan meningkat lagi dan menyebabkan terjadinya NPL yang berfluktuasi pada Koperasi Nusantara KCP Muara Bungo.

\section{Analisis Deskriptif Return On Asset (ROA)}

Return On Asset (ROA) adalah perbandingan (rasio) laba sebelum pajak yang menunjukkan perbandingan antara laba dengan total asset, rasio ini menunjukkan tingkat efisiensi pengelolaan aset yang dilakukan. Ketentuan untuk ROA minimal yang ideal bagi bank adalah 1,50\%.

Data yang digunakan adalah data perkembangan Return On Asset (ROA) pada Koperasi Nusantara KCP Muara Bungo periode tahun 2012 - 2015. Data ROA tersebut diperoleh langsung dari Koperasi Nusantara KCP Muara Bungo pada tanggal 16 Mei 2016 oleh peneliti.

Berdasarkan Tabel 6 di atas menunjukkan perkembangan Return On Asset (ROA) pada Koperasi Nusantara periode tahun 2012 2015. Pada masa penelitian ini ROA terendah terjadi pada bulan Maret 2015 yaitu sebesar 5,1440, sedangkan ROA tertinggi terjadi pada bulan Februari 2013 yaitu sebesar 14,4185.
Nusantara periode tahun 2012 - 2015. Data NPL tersebut diperoleh langsung dari Koperasi Nusantara KCP Muara Muara Bungo pada tanggal 16 Mei 2016 oleh peneliti. Seperti yang tersaji dalam tabel 5 . sedangkan NPL tertinggi terjadi pada bulan Nopember 2012 yaitu sebesar 16,8727.

Agar lebih mudah dipahami dan komunikatif data tersebut dapat di lihat melalui grafik sebagai berikut (Gambar 1).

Agar lebih mudah dipahami dan komunikatif data tersebut dapat kita lihat melalui grafik sebagai berikut (Gambar2).

Grafik diatas menggambarkan kinerja Koperasi Nusantara dilihat dari sisi profitabilitas yang diukur dengan Return On Asset (ROA), selama periode tahun 2012 2015 dapat dilihat pada grafik diatas ROA meningkat pada bulan Februari 2013 dan dibulan berikutnya menurun dan meningkat lagi sehingga mengalami fluktuasi pada laba, ROA mengalami fluktuasi yang dipicu oleh fluktuasi pada NPL di Koperasi Nusantara KCP Muara Bungo periode 2012-2015.

\section{Statistik Deskriptif}

Untuk membuktikan adanya pengaruh antara variabel bebas $(\mathrm{X})$ terhadap variabel terikat (Y), diperlukan ringkasan laporan keuangan periode tahun 2012 - 2015. Sebelum variabel penelitian dianalisis dengan pengujian rumus statistik, data dari masing-masing variabel penelitian dideskripsikan terlebih dahulu. Hal ini, dimaksudkan agar dapat memberikan gambaran tentang masing-masing variabel yang diteliti.

Data penelitian yang menjadi variabel bebas yaitu Non Performing Loan (NPL), sedangkan yang menjadi variabel terikat adalah Return On Asset (ROA).

Tabel 6 menjelaskan secara deskriptif variabel-variabel dalam penelitian ini. Variabel Return On Asset (ROA) (Y) yang terjadi pada Koperasi Nusantara KCP Muara Bungo rata-ratanya adalah sebesar 9,503606 dengan standar deviasi 2,9289267. Kualitas 
implementasi Return On Asset (ROA) (Y) yang paling tinggi (maksimum) terjadi yaitu sebesar 14,4185 dan paling rendah (minimum) yaitu sebesar 4,2186.

Variabel ukuran perusahaan Non Performing Loan (NPL) X rata-ratanya adalah sebesar 3,122308 dengan standar deviasi 2,8376948. Ukuran perusahaan paling tinggi (maksimum) yaitu sebesar 16,8727 dan yang paling rendah (minimum) yaitu sebesar 0,0536 .

\section{Hasil Uji Asumsi Klasik}

Untuk mengetahui apakah persamaan tersebut memenuhi syarat secara statistik, maka dilakukan pengujian asumsi klasik terlebih dahulu yang meliputi : uji normalitas dan uji autokorelasi yang dilakukan sebagai berikut :

\section{a. Uji Normalitas}

Uji normalitas ini bertujuan untuk menguji apakah dalam sebuah model regresi, variabel terikat dan variabel bebas keduanya mempunyai distribusi normal atau tidak. Model regresi yang baik adalah memiliki distribusi data normal atau mendekati normal. Hasil uji normalitas secara grafik Probability Plot dengan menggunakan SPSS versi, 20 untuk variabel ROA ditunjukkan dengan grafik dibawah ini (Gambar 3):

Berdasarkan gambar 3 dapat dilihat bahwa titik-titik menyebar di sekitar garis diagonal dan penyebarannya mengikuti arah garis diagonal. Dengan demikian dapat dinyatakan bahwa penyebaran data ROA memenuhi asumsi normalitas.

\section{Uji Autokorelasi}

Uji autokorelasi bertujuan untuk menguji melihat apakah dalam suatu model regresi linear ada korelasi antara suatu periode $\mathrm{t}$ dengan periode sebelumnya $(\mathrm{t}-1)$, secara sederhana adalah bahwa analisis regresi adalah untuk melihat pengaruh antara variabel bebas terhadap variabel terikat. Durbin Watson (DW) pendeteksian ada tidaknya gejala autokorelasi adalah sebagai berikut. Jika angka DW dibawah -2, berarti ada autokorelasi negatif sedangkan angka DW diantara -2 sampai 2, berarti tidak terjadi autokorelasi dan jika angka DW diatas +2 , berarti ada autokorelasi positif. Berdasarkan hasil perhitungan analisis data dengan menggunakan SPSS versi 20 diperoleh hasil uji autokorelasi dapat dilihat pada Tabel model summary (Tabel 7).

Berdasarkan hasil pengujian yang telah dilakukan, ditemukan bahwa nilai Durbin-Watson dengan variabel terikat tingkat pengungkapan laporan keuangan adalah sebesar 1,510 yang berada pada rentang -2 sampai dengan +2 , sehingga dapat disimpulkan bahwa model regresi ini bebas dari gangguan autokorelasi.

\section{Regresi Linear Sederhana}

Berikut ini adalah tabel hasil pengolahan data yang menjadi dasar dalam pembentukan model penelitian ini:

Hasil pengolahan data dengan program SPSS dapat dilihat pada tabel 10 maka diperoleh persamaan regresi sederhana sebagai berikut :

$$
\begin{gathered}
Y=\alpha+\beta X+e \\
Y=10.673-0.375 X+e
\end{gathered}
$$

Dimana :

$\mathrm{Y}=\mathrm{ROA}$

$\alpha=$ Konstanta

$\beta=$ Koefisien variabel independen

terhadap ROA

$\mathrm{X}=\mathrm{NPL}$

e $=$ Faktor Pengganggu

Angka yang dihasilkan dari pengujian tersebut dapat dijelaskan sebagai berikut:

a. Konstanta (a)

Nilai konstanta yang diperoleh sebesar 10,673. Hal ini berarti bahwa jika variabel independen Non Performing Loan (NPL) adalah tidak ada atau bernilai nol, maka besarnya 
Return On Asset (ROA) sebesar 10,673 .

b. Koefisien Regresi (b)

Nilai koefisien variabel $\mathrm{X}$ Non Performing Loan (NPL) sebesar 0,375. Hal ini menandakan bahwa NPL berpengaruh negatif terhadap Return On Asset (ROA), dimana setiap peningkatan satu satuan NPL akan mengakibatkan penurunan ROA sebesar -0,375.

\section{Hasil Pengujian Hipotesis}

\section{Uji t}

Uji t bertujuan untuk menguji pengaruh masing-masing variabel independen Non Performing Loan (NPL) terhadap variabel dependen Return On Asset (ROA). Hasil uji analisis regresi coefficients dengan menggunakan SPSS versi 20 terlihat pada tabel 11 .

Uji hipotesis dilakukan untuk mengetahui ada tidaknya pengaruh variabel independen dengan variabel dependen secara parsial. Hasil analisis uji hipotesis antara variabel independen Non Performing Loan (NPL) (X) terhadap variabel dependen Return On Asset (ROA) (Y) diperoleh hasil seperti yang terdapat pada tabel 11 .

\section{HASIL DAN PEMBAHASAN}

Pengaruh Non Performing Loan (NPL) terhadap Return On Asset (ROA) pada Koperasi Nusantara periode 2012-2015. Hasil perhitungan statistik deskriptif dalam tabel 7 menunjukkan nilai mean NPL sebesar 3,122308. Berdasarkan ketentuan SE BI No. 17/19/DPUM tanggal 8 Juli 2015 ditetapkan bahwa rasio NPL tidak boleh lebih dari 5\%. Berdasar nilai mean tersebut, bisa diambil kesimpulan bahwa rasio NPL sudah memenuhi kriteria yang ditetapkan oleh Bank Indonesia. Namun, nilai NPL masih perlu diturunkan karena angka kredit macet yang semakin kecil akan semakin baik.
Pada tabel 11 dapat dilihat bahwa NPL memiliki nilai signifikansi sebesar $0,011<\alpha 0,05$. Berarti hipotesis (Ha) diterima, hal ini menunjukkan bahwa variabel NPL (X) berpengaruh terhadap variabel ROA (Y) yang dijelaskan pada koefisien regresi sederhana. Hasil uji t NPL secara parsial $-2,641$ hasil pengujian menunjukkan bahwa NPL berpengaruh negatif terhadap ROA pada Koperasi Nusantara KCP Muara Bungo.

\section{Koefisien Determinasi $\left(\mathbf{R}^{2}\right)$}

Analisis koefisien determinasi dilakukan untuk mengetahui seberapa besar nilai presentase kontribusi variabel bebas terhadap variabel terikat. Dari hasil perhitungan didapatkan nilai koefisien determinasi sebagai berikut (Tabel 10):

Berdasarkan Tabel 12 diatas diperoleh angka $R$ Square sebesar 0,132 hal itu berarti bahwa variasi perubahan $\mathrm{Y}$ dipengaruhi oleh perubahan $\mathrm{X}$ sebesar 13,2\%. Jadi besarnya pengaruh Non Performing Loan (NPL) terhadap Return On Asset (ROA) adalah sebesar $13,2 \%$ sedangkan sisanya sebesar $86,8 \%$ dipengaruhi oleh faktor lain yang tidak teridentifikasi dalam model penelitian ini.

Pada grafik gambar 3 dapat di lihat kecenderungan NPL yang mengalami fluktuasi pada Koperasi Nusantara periode tahun 2012 - 2015, dapat dilihat pada grafik diatas NPL meningkat pada bulan Nopember 2012 disebabkan banyaknya debitur yang tidak mengambil gaji dan membuat tingginya tingkat NPL. Karena di Koperasi Nusantara ini untuk pemotongan angsuran kredit pensiunnya, pihak PT. Pos Indonesia akan memotong angsuran kreditnya dari gaji yang diterima pensiunan ketika pensiun tersebut mengambil gaji, seperti itu prosedur kerjasama antara Koperasi Nusantara bersama PT. Pos Indosesia untuk pemotongan angsuran kreditnya. Maka jika pensiun tersebut tidak datang untuk 
mengambil gaji maka pihak PT. Pos Indonesia tidak berani untuk memotong gajinya tanpa melihat langsung keadaan pensiun itu sendiri. Pada bulan berikutnya menurun dan meningkat lagi sehingga menyebabkan terjadinya NPL yang berfluktuasi pada Koperasi Nusantara KCP Muara Bungo.

Pada grafik gambar 4 menggambarkan kinerja Koperasi Nusantara dilihat dari sisi profitabilitas yang diukur dengan Return On Asset (ROA), selama periode tahun $2012-$ 2015 dapat dilihat pada grafik diatas ROA meningkat pada bulan Februari 2013 dan dibulan berikutnya menurun dan meningkat lagi sehingga mengalami fluktuasi pada laba, ROA mengalami fluktuasi yang dipicu oleh fluktuasi pada NPL di Koperasi Nusantara KCP Muara Bungo periode 2012-2015.

Secara parsial NPL memiliki nilai signifikansi sebesar $0,011<\alpha 0,05$. yang menunjukkan bahwa variabel NPL (X) berpengaruh signifikan terhadap variabel ROA (Y) karena lebih kecil dari $\alpha$. Hasil uji $\mathrm{t}-2,641$ menunjukkan berpengaruh negatif terhadap ROA pada Koperasi Nusantara KCP Muara Bungo. Ini berarti semakin tinggi tingkat NPL maka ROA akan semakin menurun. Tanda negatif menunjukkan perubahan yang berlawanan atau berbanding terbalik, yaitu jika variabel (X) NPL meningkat maka variabel (Y) ROA akan menurun. Sebaliknya apabila variabel $(\mathrm{X})$ NPL menurun maka variabel (Y) ROA akan meningkat.

Nilai koefisien determinasi ( $R$ Square) sebesar 0,132 hal itu berarti bahwa variasi perubahan $\mathrm{Y}$ dipengaruhi oleh perubahan $\mathrm{X}$ sebesar $13,2 \%$. Jadi besarnya pengaruh Non Performing Loan (NPL) terhadap Return On Asset (ROA) adalah sebesar 13,2\% sedangkan sisanya sebesar $86,8 \%$ dipengaruhi oleh faktor lain yang tidak teridentifikasi dalam model penelitian ini. Nilai 13,2\% menunjukkan bahwa NPL dapat mempengaruhi ROA setiap bulannya sebesar
$13,2 \%$, sehingga manajemen Koperasi Nusantara seharusnya lebih selektif dalam penyaluran kredit yang diberikan kepada debitur, agar dapat meminimalisir terjadinya risiko kredit macet.

Hasil penelitian yang dilakukan Agus Pauzi (2011) mengenai Analisis dana pihak ketiga, Non Performing Loan, Capital Adequecy Ratio, dan Loan To Deposit Ratio terhadap Return On Asset serta implikasinya terhadap penyaluran kredit pada Bank Persero. Hasil perhitungan menunjukkan angka $0,000<0,05$ maka NPL memiliki pengaruh yang negatif dan signifikan pada ROA. Artinya apabila NPL terjadi kenaikan maka ROA mengalami penurunan. Peningkatan NPL akan mempengaruhi profitabilitas bank, karena semakin tinggi NPL maka akan semakin buruk kualitas kredit bank yang menyebabkan jumlah kredit bermasalah semakin besar .

Hasil penelitian yang dilakukan Kuntari Dasih (2014) mengenai Pengaruh Rasio Keuangan Terhadap Return On Asset Perbankan (Studi pada Bank Umum yang Terdaftar di Bursa Efek Indonesia Periode 2007-2013), menemukan bahwa NPL tidak signifikan berpengaruh terhadap ROA dengan koefisien sebesar 0.0153103 dan signifikan sebesar 0.394, hasil yang diperoleh menunjukkan bahwa NPL berpengaruh positif tetapi tidak signifikan terhadap ROA. Dalam hal ini earning asset bukan merupakan satu-satunya pendapatan yang diandalkan bank, maka kredit bermasalah atau NPL tidak memberikan pengaruh yang signifikan terhadap keuntungan bank. Hal ini dikarenakan kerugian dari adanya kredit bermasalah masih bisa ditutup dengan pendapatan lain yaitu fee base income.

Hasil penelitian yang dilakukan Hardiyanti (2012) mengenai Pengaruh CAR, NPL dan $L D R$ Terhadap ROA pada Bank BUMN yang Go-Public di Indonesia (Tahun 2006-2010), dari hasil penelitian diperoleh 
nilai signifikansi sebesar 0,031 , dilihat dari tingkat signifikansinya menunjukkan bahwa nilai signifikansinya lebih kecil dari 0,05 yaitu sebesar 0,031 menemukan bahwa variabel Non Performing Loan (NPL) berpengaruh negatif dan signifikan terhadap Return On Asset (ROA) pada Bank BUMN Go Publik di Indonesia.

Hasil penelitian yang dilakukan Nazrantika Sunarto (2013) mengenai pengaruh karakteristik Non Performing Loan (NPL) terhadap Return On Asset (ROA) pada sektor perbankan di Indonesia, diperoleh nilai (sig) sebesar 0,035 lebih kecil dari pada 0,05 maka dapat disimpulkan bahwa Non Performing Loan (NPL) berpengaruh negatif terhadap Return On Asset (ROA). Hasil penelitian yang dilakukan Farah Margaretha dan Marshelly Pingkan Zai (2013) Faktor-faktor yang mempengaruhi kinerja keuangan perbankan Indonesia, dari hasil penelitian diperoleh nilai signifikansi sebesar 0,026 lebih kecil dari 0,05 Yang menunjukkan bahwa NPL berpengaruh negatif signifikan terhadap ROA dengan demikian dapat disimpulkan bahwa semakin besar Non Performing Loan (NPL) maka Return On Asset (ROA) yang diperoleh akan semakin kecil. Hasil penelitian yang dilakukan Hilaluddin Arga Saputra (2013) Faktor yang mempengaruhi kinerja keuangan perusahaan perbankan yang terdaftar di BEI (Tahun 2011-2013), menemukan hasil dengan nilai signifikan sebesar 0,453 lebih besar dari taraf signifikan yaitu 0,05 artinya bahwa Non Performing Loan (NPL) tidak berpengaruh terhadap kinerja keuangan bank Return On Asset (ROA).

Temuan dari hasil penelitian ini Pengaruh Non Performing Loan (NPL) terhadap Return On Asset (ROA) sejalan dengan penelitian dari Agus Pauzi (2011), Hardiyanti (2012), Nazrantika Sunarto (2013), Farah Margaretha dan Marshelly Pingkan Zai (2013) dari beberapa penelitian sebelumnya yang menunjukkan bahwa NPL mempunyai pengaruh yang negatif terhadap ROA. Artinya semakin besar tingkat NPL pada perusaahan tersebut maka ROA mengalami penurunan.

Hasil penelitian ini berbeda dengan penelitian yang dilakukan oleh Kuntari Dasih (2014) bahwa Non Performing Loan (NPL) berpengaruh positif terhadap Return On Asset (ROA). Hasil penelitian ini juga berbeda dengan hasil penelitian Hilaluddin Arga Saputra (2013) bahwa Non Performing Loan (NPL) tidak berpengaruh terhadap Return On Asset (ROA), artinya tidak berdampak bagi perusahaan dalam menghasilkan laba.

Hasil penelitian ini sebagai bukti empiris mendukung teori bahwa kinerja keuangan perusahaan dalam menghasilkan laba, indikator ROA menjadi salah satu alat untuk mengukur kemampuan perusahaan dalam menggunakan asetnya dengan baik dan memiliki kualitas kredit sesuai dengan standar BI.

\section{SIMPULAN}

Berdasarkan analisis data dan pembahasan hasil penelitian, dapat ditarik kesimpulan sebagai berikut :

1. Dari hasil penelitian menunjukkan variabel NPL berpengaruh negatif dan signifikan terhadap ROA. Artinya, setiap perubahan yang terjadi pada variabel independen yaitu NPL akan berpengaruh pada ROA di Koperasi Nusantara KCP Muara Bungo.

2. Secara parsial variabel NPL berpengaruh negatif terhadap ROA pada Koperasi Nusantara. Tanda negatif menunjukkan perubahan yang berlawanan atau berbanding terbalik, yaitu jika variabel (X) NPL meningkat maka variabel (Y) ROA akan menurun. Sebaliknya apabila variabel (X) NPL menurun maka variabel (Y) ROA akan meningkat. 
Ilustrasi

Tabel 1. Persentase NPL Koperasi Nusantara KCP Muara Bungo Periode 2012-2015

\begin{tabular}{|c|c|c|c|c|}
\hline No. & Tahun & Total Kredit & Kredit Bermasalah & NPL \\
\hline 1. & 2012 & $\operatorname{Rp} 5.086 .800 .000,-$ & $\operatorname{Rp~107.738.503,-}$ & $2,12 \%$ \\
\hline 2. & 2013 & $\operatorname{Rp} 6.769 .140 .000,-$ & $\operatorname{Rp~75.162.300,-~}$ & $1,11 \%$ \\
\hline 3. & 2014 & $\operatorname{Rp} 6.667 .209 .000,-$ & $\operatorname{Rp~133.406.101,--~}$ & $2 \%$ \\
\hline 4 & 2015 & $\operatorname{Rp} 4.628 .161 .999,-$ & $\operatorname{Rp} 211.789 .970,-$ & $4,58 \%$ \\
\hline
\end{tabular}

Sumber : Koperasi Nusantara, 2016

Tabel 2. Persentase ROA Koperasi Nusantara KCP Muara Bungo

Periode 2012-2015

\begin{tabular}{|c|c|c|c|c|}
\hline No. & Tahun & Laba Sebelum Pajak & Total Asset & ROA \\
\hline 1. & 2012 & Rp 16.270.038.891,- & Rp 174.995.378.745,- & $9,30 \%$ \\
\hline 2. & 2013 & Rp 19.056.749.082,- & Rp 171.340.935.020,- & $11,12 \%$ \\
\hline 3. & 2014 & Rp 17.081.329.667,- & Rp 169.239.377.948,- & $10,09 \%$ \\
\hline 4 & 2015 & Rp 13.931.998.124,- & Rp 185.599.741.053,- & $7.51 \%$ \\
\hline
\end{tabular}

Sumber : Koperasi Nusantara, 2016

Tabel 3. Operasional Variabel

\begin{tabular}{|c|c|c|c|c|}
\hline No. & Variabel & Definisi & Skala & Pengukuran \\
\hline 1. & $\begin{array}{c}\text { NPL } \\
(\mathrm{X})\end{array}$ & $\begin{array}{l}\text { Perbandingan } \\
\text { antara kredit } \\
\text { bermasalah } \\
\text { dengan total } \\
\text { kredit yang } \\
\text { diberikan. }\end{array}$ & Rasio & $\begin{array}{l}\text { NPL }=\frac{\text { Kredit Bermasalah }}{\text { Total Kredit }} \\
\text { Satuan }: \text { Persen }(\%)\end{array}$ \\
\hline 2. & $\begin{array}{c}\text { ROA } \\
\text { (Y) }\end{array}$ & $\begin{array}{l}\text { Untuk mengukur } \\
\text { kemampuan } \\
\text { manajemen } \\
\text { dalam } \\
\text { memperoleh } \\
\text { keuntungan } \\
\text { secara } \\
\text { keseluruhan. }\end{array}$ & Rasio & $\begin{array}{l}\text { ROA } \\
=\frac{\text { Laba Sebelum Pajak }}{\text { Rata - Rata Total Aset }} \\
\text { Satuan : Persen }(\%)\end{array}$ \\
\hline
\end{tabular}

Tabel 4. Data Non Performing Loan (NPL) Periode 2012-2015

\begin{tabular}{|c|l|c|c|c|c|}
\hline \multirow{2}{*}{ No. } & \multirow{2}{*}{ Bulan } & \multicolumn{4}{|c|}{ Tahun } \\
\cline { 3 - 6 } & & 2012 & 2013 & 2014 & 2015 \\
\hline 1. & Januari & 0.6429 & 2.1378 & 3.5494 & 1.3939 \\
\hline 2. & Februari & 0.4322 & 1.4377 & 0.6975 & 7.0940 \\
\hline 3. & Maret & 1.3510 & 6.1372 & 0.6220 & 4.1465 \\
\hline 4. & April & 5.7223 & 1.8467 & 0.9568 & 5.5717 \\
\hline 5. & Mei & 2.5502 & 1.1344 & 2.2910 & 3.9213 \\
\hline 6. & Juni & 3.0085 & 0.9775 & 0.7970 & 6.0056 \\
\hline 7. & Juli & 2.3550 & 0.0536 & 2.3058 & 6.4294 \\
\hline 8. & Agustus & 5.1714 & 0.5612 & 3.3918 & 6.8592 \\
\hline 9. & September & 2.0541 & 0.3567 & 2.1095 & 5.4580 \\
\hline
\end{tabular}




\begin{tabular}{|l|l|c|c|c|c|}
\hline 10. & Oktober & 2.1817 & 1.6627 & 2.3094 & 5.6773 \\
\hline 11. & Nopember & 16.8727 & 1.6727 & 3.6142 & 3.8784 \\
\hline 12. & Desember & 2.5359 & 0.9690 & 1.9340 & 5.0320 \\
\hline
\end{tabular}

Sumber : Data diolah (2016)

Tabel 5. Data Return On Asset (ROA) Periode 2012-2015

\begin{tabular}{|c|l|c|c|c|c|}
\hline \multirow{2}{*}{ No. } & \multirow{2}{*}{ Bulan } & \multicolumn{4}{|c|}{ Tahun } \\
\cline { 3 - 6 } & & 2012 & 2013 & 2014 & 2015 \\
\hline 1. & Januari & 11.2677 & 13.3143 & 6.4831 & 6.1993 \\
\hline 2. & Februari & 13.3763 & 14.4185 & 6.4032 & 10.5295 \\
\hline 3. & Maret & 12.0648 & 13.5854 & 12.8749 & 5.1440 \\
\hline 4. & April & 7.3095 & 6.5064 & 13.4893 & 4.2186 \\
\hline 5. & Mei & 12.1538 & 11.5012 & 12.5669 & 11.0413 \\
\hline 6. & Juni & 7.9021 & 12.1596 & 12.1521 & 11.7009 \\
\hline 7. & Juli & 7.8973 & 12.9323 & 7.2136 & 5.4760 \\
\hline 8. & Agustus & 7.6946 & 11.2236 & 13.4848 & 6.1601 \\
\hline 9. & September & 6.1642 & 8.2277 & 13.5586 & 5.5559 \\
\hline 10. & Oktober & 7.8799 & 8.9010 & 8.5760 & 6.3390 \\
\hline 11. & Nopember & 6.7703 & 9.8552 & 9.1373 & 8.3408 \\
\hline 12. & Desember & 11.2078 & 10.8954 & 5.2083 & 9.1107 \\
\hline
\end{tabular}

Sumber : Data diolah (2016)

Tabel 6. Hasil Statistik Deskriptif Descriptive Statistics

\begin{tabular}{|l|r|r|r|r|r|l|}
\hline & $\mathrm{N}$ & Minimum & Maximum & Sum & Mean & $\begin{array}{c}\text { Std. } \\
\text { Deviation }\end{array}$ \\
\hline $\mathrm{X}$ & 48 & .0536 & 16.8727 & 149.8708 & 3.122308 & 2.8376948 \\
$\mathrm{Y}$ & 48 & 4.2186 & 14.4185 & 456.1731 & 9.503606 & 2.9289267 \\
Valid N & 48 & & & & & \\
(listwise) & & & & & & \\
\hline
\end{tabular}

Sumber: Pengolahan data statistik, 2016

Tabel 7. Hasil Uji Autokorelasi

Model Summary ${ }^{\mathrm{b}}$

\begin{tabular}{|l|c|r|r|r|r|}
\hline Model & $\mathrm{R}$ & $\mathrm{R}$ Square & $\begin{array}{c}\text { Adjusted R } \\
\text { Square }\end{array}$ & $\begin{array}{c}\text { Std. Error of the } \\
\text { Estimate }\end{array}$ & $\begin{array}{c}\text { Durbin- } \\
\text { Watson }\end{array}$ \\
\hline 1 & $.363^{\mathrm{a}}$ & .132 & .113 & 2.7587711 & 1.510 \\
\hline
\end{tabular}

a. Predictors: (Constant), X

b. Dependent Variable: Y

Tabel 8.

Hasil Analisis Regresi Linear Sederhana

Coefficients $^{\mathbf{a}}$

\begin{tabular}{|c|c|c|c|c|c|}
\hline \multirow[t]{2}{*}{ Model } & \multicolumn{2}{|c|}{$\begin{array}{l}\text { Unstandardized } \\
\text { Coefficients }\end{array}$} & $\begin{array}{l}\text { Standardized } \\
\text { Coefficients }\end{array}$ & \multirow[t]{2}{*}{$\mathrm{t}$} & \multirow[t]{2}{*}{ Sig. } \\
\hline & B & Std. Error & Beta & & \\
\hline (Constant) & 10.673 & .595 & & 17.923 & .000 \\
\hline$X$ & -.375 & .142 & -.363 & -2.641 & .011 \\
\hline
\end{tabular}

a. Dependent Variable: $Y$ 
Tabel 9.

Hasil Uji t

Coefficients $^{\mathbf{a}}$

\begin{tabular}{|c|c|c|c|c|c|}
\hline \multirow[t]{2}{*}{ Model } & \multicolumn{2}{|c|}{$\begin{array}{c}\text { Unstandardized } \\
\text { Coefficients }\end{array}$} & $\begin{array}{l}\text { Standardized } \\
\text { Coefficients }\end{array}$ & \multirow[t]{2}{*}{$\mathrm{t}$} & \multirow[t]{2}{*}{ Sig. } \\
\hline & B & Std. Error & Beta & & \\
\hline (Constant) & 10.673 & .595 & & 17.923 & .000 \\
\hline$X$ & -.375 & .142 & -.363 & -2.641 & .011 \\
\hline
\end{tabular}

a. Dependent Variable: Y

Tabel 10.

Uji Koefisien Determinasi

Model Summary ${ }^{b}$

\begin{tabular}{|l|r|r|r|r|r|}
\hline $\begin{array}{l}\text { Mode } \\
1\end{array}$ & \multicolumn{1}{|c|}{$\mathrm{R}$} & R Square & $\begin{array}{c}\text { Adjusted R } \\
\text { Square }\end{array}$ & $\begin{array}{c}\text { Std. Error of the } \\
\text { Estimate }\end{array}$ & $\begin{array}{c}\text { Durbin- } \\
\text { Watson }\end{array}$ \\
\hline 1 & $.363^{\mathrm{a}}$ & .132 & .113 & 2.7587711 & 1.510 \\
\hline
\end{tabular}

a. Predictors: (Constant), $X$

b. Dependent Variable: Y

Gambar 1. Grafik Non Performing Loan (NPL) Periode 2012-2015

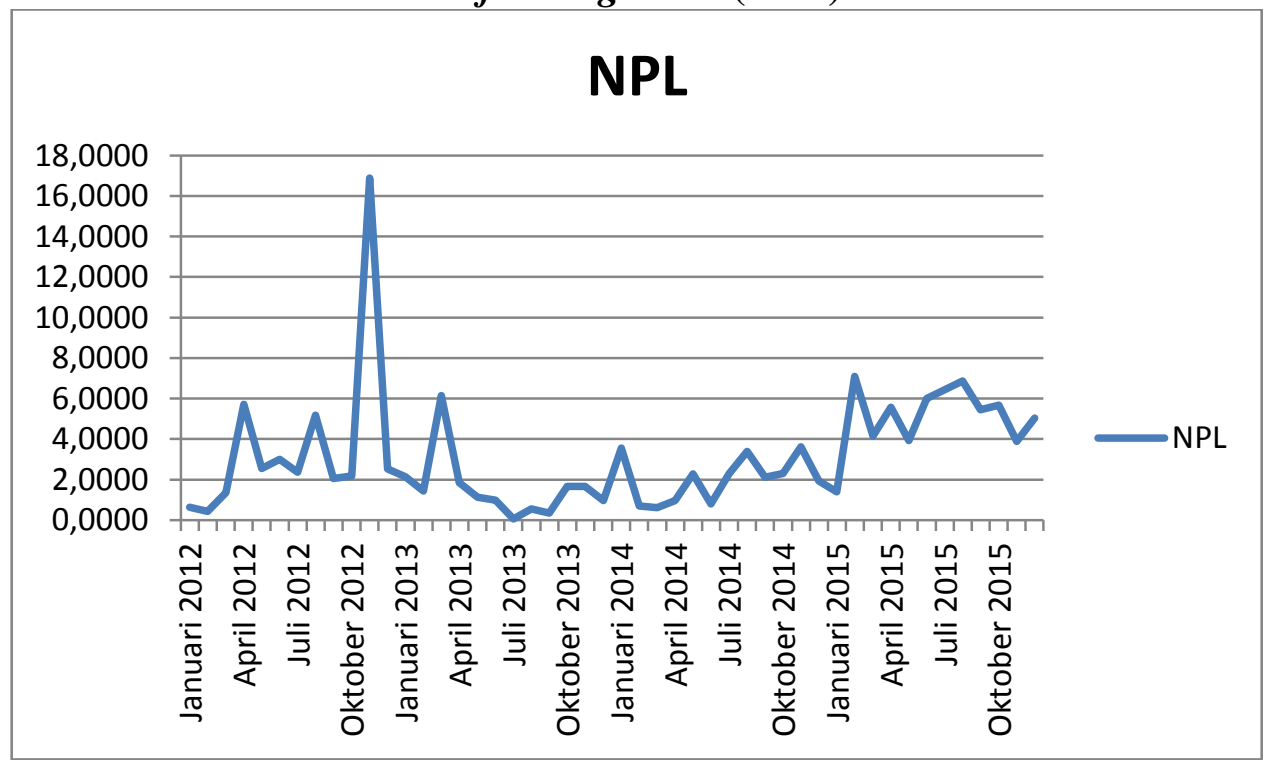

Sumber : Data diolah

Gambar 2. Grafik Return On Asset (ROA) Periode 2012-2015 


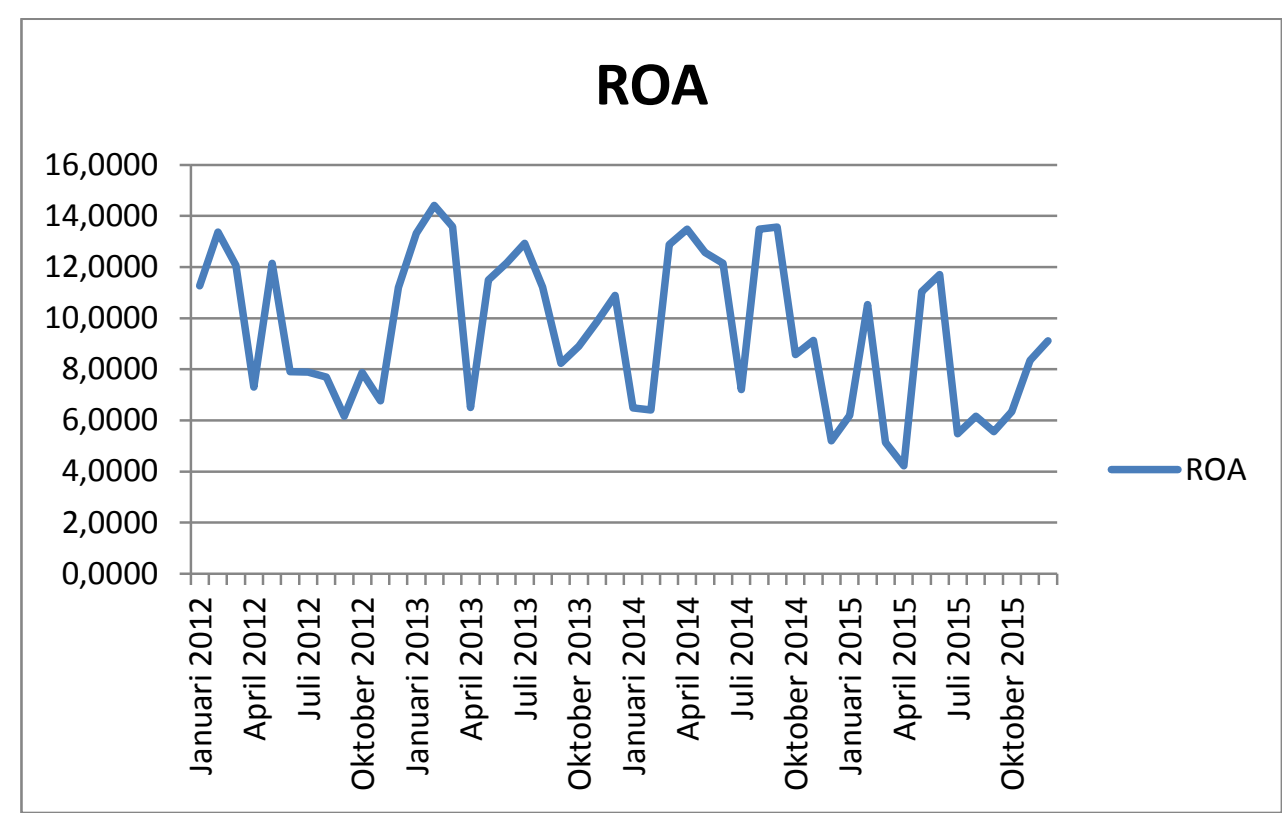

Sumber : Data diolah

Gambar 3. Hasil Uji Normalitas

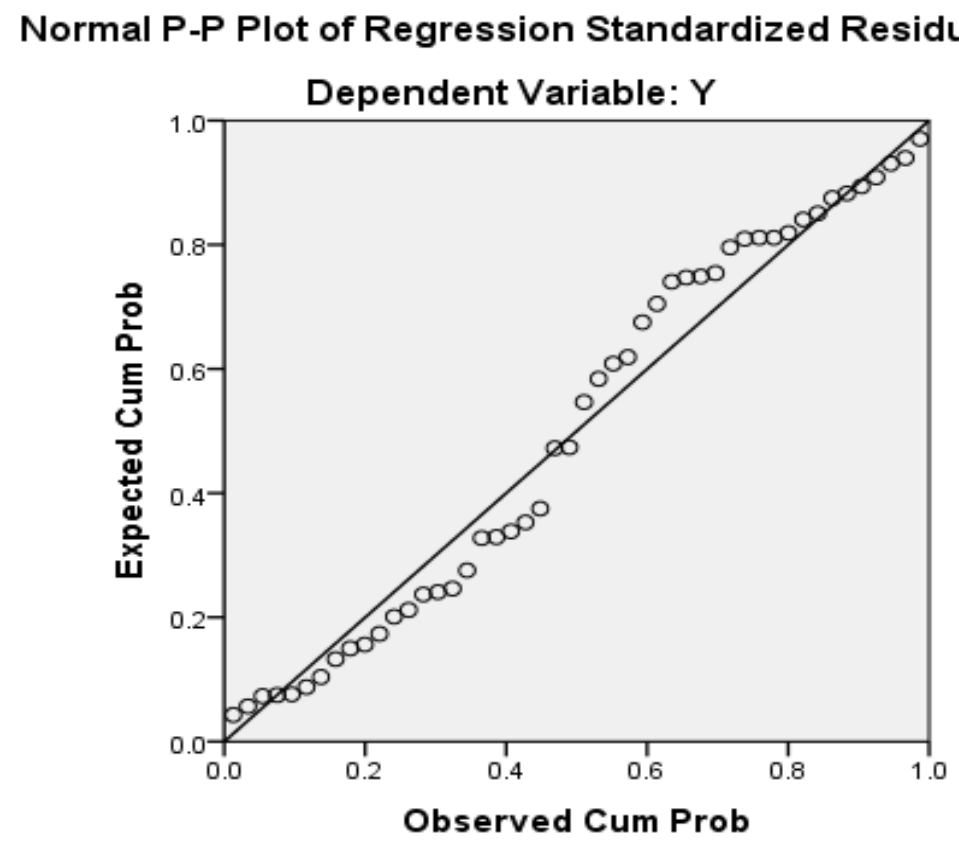

\section{DAFTAR PUSTAKA}

Analisis pengaruh rasio roa, ldr, nim dan npl terhadap. (n.d.), (6), 351-367.

Barseghyan, L. (2003). Non Performing Loans, Prospective Bailouts, and Japan's Slowdown.

Beck, R., \& Jakubik, P. (2013). to the economic cycle?
Car, A. P., Suku, D. A. N., \& Sbi, B. (2009). ( Studi Pada Bank Devisa di Indonesia Perioda 2003-2007) Sertifikasi.

Car, P., Dan, N. P. L., \& Terhadap, R. O. A. (2010). Pengaruh car, npl dan roa terhadap penyaluran kredit modal kerja. Editors, A., Jadhav, N., Singh, B., Patra, M. D., Ranjan, R., Kapur, M., \& Bose, D. 
(n.d.). Editorial committee, 1(1036).

Ghosh, A. (2015). Banking-industry specific and regional economic determinants of non-performing loans : Evidence from US states, 20, 93-95.

Grosvenor, T. (n.d.). FORECASTING NON-PERFORMING LOANS IN BARBADOS KEVIN GREENIDGE.

Haneef, S., Rana, M. A., \& Karim, Y. (2012). Impact of Risk Management on Non-Performing Loans and Profitability of Banking Sector of Pakistan Hailey College of Commerce University of the Punjab Hafiz Muhammad Ishaq Federal Urdu University of Arts, Science and Technology, 3(7), 307-315.

Kasus, S., Bank, P., \& Syariah, U. (2012). ANALISIS PENGARUH UKURAN PERUSAHAAN , KECUKUPAN MODAL, KUALITAS AKTIVA PRODUKTIF DAN LIKUIDITAS TERHADAP RETURN ON ASSETS ( ROA ).

Kel, A., \& Ah, I. L. M. I. (2013). Sekolah tinggi ilmu ekonomi perbanas surabaya 2013.

Klein, N. (n.d.). Non-Performing Loans in CESEE : Determinants and Impact on Macroeconomic Performance.

Louzis, D. P., Vouldis, A. T., \& Metaxas, V. L. (2011). Macroeconomic and bankspecific determinants of nonperforming loans in Greece : A comparative study of mortgage , business and consumer loan portfolios. JOURNAL OF BANKING FINANCE. https://doi.org/10.1016/j.jbankfin.2011. 10.012

Makri, V. (2014). Determinants of NonPerforming Loans : The Case of Eurozone, 77(April 2013), 193-206. https://doi.org/10.2298/PAN1402193M

Messai, A. S. (2013). Micro and Macro Determinants of Non-performing Loans, 3(4), 852-860.
No Title. (2014).

No Title. (2018).

Ppap, D. A. N. (2006). ANALISIS

PENGARUH KECUKUPAN MODAL , ( Studi Empiris : Pada Industri Perbankan Yang Listed di BEJ Periode Tesis Sertifikasi.

Publik, D. A. N. (2008). ANALISIS KINERJA KEUANGAN BANK : PENDEKATAN RASIO NPL, LDR, BOPO DAN ROA PADA BANK PRIVAT DAN PUBLIK Nuresya Meliyanti, 1-14.

Roa, P., Perkreditan, B., \& Di, R. (n.d.). Perbankan yang segmen pasarnya lebih banyak pada pengusaha UKM (Usaha, Kecil dan Menengah) adalah Bank Prekreditan Rakyat (BPR). BPR. Škarica, B. (2013). Determinants of nonperforming loans in Central and Eastern European countries. https://doi.org/10.3326/fintp.38.1.2

Fahmi, I. (2014). Manajemen Perkreditan . Bandung: Alfabeta.

Fahmi, I. (2013). Manajemen Resiko . Bandung: Alfabeta.

Gozali, I. (2006). Aplikasi Analisis Multivariate dengan Program SPSS. Semarang: Undip.

Hasibuan, M. S. (2011). Dasar-Dasar Perbankan. Jakarta: Bumi Aksara.

Kasmir. (2011). manajemen Perbankan . Jakarta: Raja Grafindo Persada.

Sugiono, A. (2009). Manajemen Keuangan. jakarta: Gasindo.

Sugiyono. (2012). Metode PenelitianAdministrasi. Bandung: Alfabeta.

Tukiran, S. E. (2014). Metode Penelitian Survei. Jakarta: LP3ES.

Zaini, Z. (2015). Bisnis Kredit Perbankan . Jakarta: Gramedia Pustaka Utama. 